\title{
Conjectures. Logic and the Thomistic Debate on Human Freedom and the Divine Causality
}

\author{
Walter Redmond \\ University of Texas-Austin \\ wbredmond@gmail.com
}

\begin{abstract}
In the question of human freedom, the theist is worse off than the non-believer. Both must explain how I can perform a free act in a physically determined universe. But the theist must also explain how I can act freely in a universe where God not only causes everything but also knows what I shall do. If the theist is a Christian, he has one more problem: he must reconcile human freedom not only with divine causality and omniscience (the philosophical problem), but with supernatural grace as well (the theological problem). I wish to reflect here only on the philosophical issue, which I think is fundamental to theological solutions.
\end{abstract}

Keywords: freedom, god, theist, modal logic, predestination, Saint Thomas Aquinas 
Sed in hac haerentium sibi serie causarum estne ulla nostri arbitrii libertas an ipsos quoque humanorum motus animorum fatalis catena constringit?

Boethius $^{1}$

In the question of human freedom, the theist is worse off than the non-believer. Both must explain how I can perform a free act in a physically determined universe. But the theist must also explain how I can act freely in a universe where God not only causes everything but also knows what I shall do. If the theist is a Christian, he has one more problem: he must reconcile human freedom not only with divine causality and omniscience (the philosophical problem), but with supernatural grace as well (the theological problem). I wish to reflect here only on the philosophical issue, which I think is fundamental to theological solutions.

To do this, I shall need modal logic, the logic of necessity and contingency; indeed, without logic these issues cannot be properly analyzed. Modal logic was rediscovered in the last century, and now enjoys its most sophisticated development. "Rediscovered," because the Scholastics from the 14th century worked out basically the same logic and applied it to philosophical issues, especially, in the $16^{\text {th }}$ and $17^{\text {th }}$ centuries, to the riddles of freedom and grace.

First I shall determine what must be the case, logically, if an act is free, and briefly mention St. Thomas's notion of predestination and freedom. Then I'll treat the freedom-determination problem, defining from the logical viewpoint the "leftwing" and "right-wing" positions of Thomas's followers as well as of 16th-century Protestants. Finally I'll offer a contribution of my own.

I shall use these symbols, where $p$ and $q$ are any events or states of affairs: $\sim p$ (not $\mathrm{p}), \mathrm{p} \wedge \mathrm{q}(\mathrm{p}$ and $\mathrm{q}), \mathrm{p} \supset \mathrm{q}$ (if $\mathrm{p}$ then $\mathrm{q}), \mathrm{p} \equiv \mathrm{q}(\mathrm{p}$ if and only if $\mathrm{q}$, equivalent to $\mathrm{p} \supset \mathrm{q}$ and $\mathrm{q} \supset$ $\mathrm{p}$ together), $\diamond \mathrm{p}$ (it's possible that $\mathrm{p}$ ), $\square \mathrm{p}$ (it's necessary that $\mathrm{p}$ ). I also suppose these modal entailments: $\mathrm{p} \supset \diamond \mathrm{p}$ ("ab esse ad posse valet illatio") and $\square \mathrm{p} \supset \mathrm{p}$ ("a necesse ad esse valet illatio").

\footnotetext{
1 "But in this series of causes linked to one another, is there any freedom at all for our will, or does this fatal chain bind as well even the motions of the minds of men?" Boethius, De consolatione philosophiae, Book 5, Prosa 2.
} 


\section{The logic of freedom}

The British philosopher G. E. Moore said that an act is free if the person who performed it could have acted differently. ${ }^{2}$ As an example, let us use Caesar choosing to cross the Rubicon in 49 B.C. As Caesar made his decision it was possible at the same time that he did not make it. If " $\mathrm{C}$ " stands for the event of Caesar's choosing, we can see the logical situation suggested by Moore in this way:

\section{$\mathrm{C} \wedge \diamond \sim \mathrm{C}$}

"Caesar chose to cross the Rubicon but it was possible that he did not so choose."3 We'll say that any formula like this $(\mathrm{p} \wedge \diamond \sim \mathrm{p})$ means $\mathrm{C}$ is logically contingent ( $\mathrm{C}$ is a fact but $\sim \mathrm{C}$ is a possibility). ${ }^{4}$

Any free act must be contingent. If we affirm $C$ but deny $\diamond \sim C$-that is, if we affirm $\sim \diamond \sim \mathrm{C}$ ) - we are saying that $\mathrm{C}$ is not only a fact but that it is logically necessary: $\square \mathrm{C}$ (since $\sim \diamond \sim \mathrm{C}$ is equivalent to $\square \mathrm{C}$ ). ${ }^{5}$

Now, let us say that a twig fell into the Rubicon blown by the wind, and call this event "T." Is T contingent? I mean: is it true to say

\section{$\mathrm{T} \wedge \diamond \sim \mathrm{T}$}

"the twig fell into the Rubicon but it is possible that it did not fall into it"? Yes, and for the same reason: if we deny $\diamond \sim \mathrm{T}$ we get $\square \mathrm{T}$, and it is false to say that $\mathrm{T}$ is logically necessary.

$\mathrm{T}$, then, is just as contingent as $C$, but it is not free, because as the twig was blown into the stream it was just following physical law. So although contingency is a necessary condition of Caesar's freedom ("if free then contingent") as Moore held, contingency is not a sufficient condition of his freedom (false: "if contingent then free"). For Caesar to have acted freely we must add that his choosing was not physically determined.

What does "physically determined" mean logically? To say that $\mathrm{T}$ is physically necessary means that $\mathrm{T}$ is necessarily entailed by physical law. If we let " $\mathrm{L}$ " stand

\footnotetext{
2 "The statement that we have free will is certainly ordinarily understood to imply that we really sometimes have the power of acting differently from the way in which we actually do act." Moore, G.E., Ethics, ch. 6.

${ }^{3}$ We understand the time element to be included in the state-of-affairs or proposition.

${ }^{4}$ Contingency in a broader sense is $\diamond \mathrm{p} \wedge \diamond \sim \mathrm{p}$, entailed by $\mathrm{p} \wedge \diamond \sim \mathrm{p}$.

${ }^{5} \sim \diamond \sim \mathrm{C} \equiv \square \mathrm{C}$, or in general $\sim \diamond \sim \mathrm{p} \equiv \square \mathrm{p}$.
} 
for the state-of-affairs "the physical laws of nature are in force", ${ }^{6}$ we can say that $\mathrm{T}$ was physically necessary in this way:

$$
\square[\mathrm{L} \supset \mathrm{T}]
$$

"necessarily, if physical law was in effect, then the twig fell into the Rubicon."

And so to say that $C$ is not physically necessary, we just negate this formula:

$\sim[\mathrm{L} \supset \mathrm{C}]$

"it was not necessary that if physical law was in effect, Caesar decided to cross the Rubicon." And saying this is logically equivalent to saying

$\diamond[\mathrm{L} \wedge \sim \mathrm{C}]$

"it is possible that physical law was in effect but Caesar did not decide to cross the Rubicon." 7

We should repeat that neither T nor $\mathrm{C}$ are logically necessary; that is, it is possible that they never will have come about:

$\sim \mathrm{T}$ (or equivalently $\diamond \sim \mathrm{T}$ )

$\sim \square$ (or $\diamond \sim \mathrm{C}) .^{8}$

What is necessary in physical determination is the entailment LÉT.

So here are some conclusions:

* Putting all this together, we can define the modal status of $\mathrm{T}$ and $\mathrm{C}$ as:

$\mathrm{T} \wedge \diamond \sim \mathrm{T} \wedge \square[\mathrm{L} \square \mathrm{T}]$

" $\mathrm{T}$ is the case, it is possible that $\mathrm{T}$ is not the case, and $\mathrm{T}$ must follow from the operation of physical law," and

$\mathrm{C} \wedge \diamond \sim \mathrm{C} \wedge \diamond[\mathrm{L} \wedge \sim \mathrm{C}]$

" $\mathrm{C}$ is the case, it is possible that $\mathrm{C}$ is not the case and it is possible that $\mathrm{C}$ is not the case when physical law is in effect."

6 "L" is the infinite logical conjunction of all the physical laws of nature; Cf. FITcH, F. B., Symbolic Logic/ An Intro-

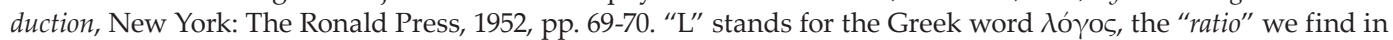
nature.

${ }^{7} \sim \square[\mathrm{L} \supset \mathrm{C}] \equiv \diamond[\mathrm{L} \wedge \sim \mathrm{C}]$.

$8 \sim \square \mathrm{T} \equiv \diamond \sim \mathrm{T}$. 
${ }^{*}$ But since $\diamond \sim \mathrm{C}$ already follows from $\diamond[\mathrm{L} \wedge \sim \mathrm{C}],{ }^{9}$ we can simplify the formula in this way:

\section{$\mathrm{C} \wedge \triangleright[\mathrm{L} \wedge \sim \mathrm{C}]$}

"Caesar decided to cross the Rubicon and it is possible that he did not cross it as physical law was in force." We could also add that both T and C are logically possible $(\diamond \mathrm{T}$ and $\diamond \mathrm{C})$, since they are already the case. ${ }^{10}$

* Both T and C are contingent. Indeed, this formula ( $\mathrm{p} \wedge \diamond \sim \mathrm{p})$ defines our modal status as creatures; we are, after all, but need not be.

* We must deny contingency of God, since He not only is He "Who is," but He Who is bound to be; God is logically necessary:

$\square \mathrm{D}$

or equivalently, God cannot not be: $\sim \diamond \sim \mathrm{D}$.

* Human beings like us and Caesar are different from merely physical things like twigs because we are free and they are not.

By the way, it is important to take "free" in its usual sense (Moore insists on this), because some have defined it in a Pickwickian sense to sidestep the real problem. For example, the Argentinian author Jorge Luis Borges said "I am free" just means "I don't know the cause," and "soft determinists" say that my act is free when it issues from things like my "character" (they don't mention that "characters" are caused).

\section{St. Thomas on freedom}

St. Thomas would probably hold for what I just said about freedom. He included the following explanation when speaking of predestination. He spoke of the whole ("common") situation and of a particular aspect of it:11

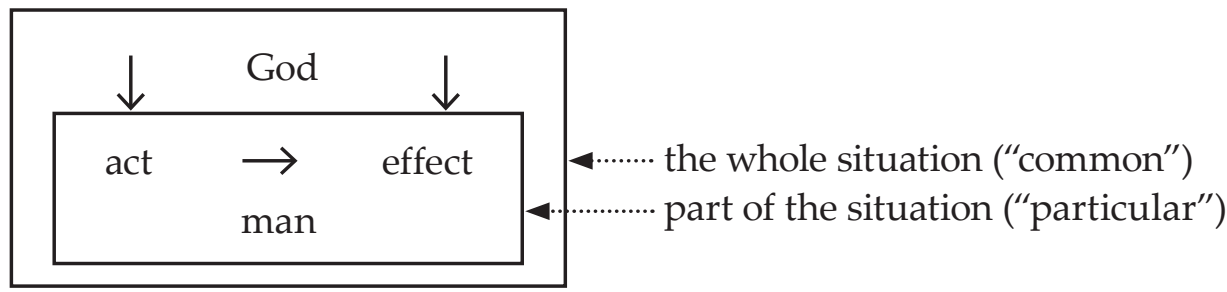

\footnotetext{
${ }^{9} \diamond[\mathrm{L} \wedge \sim \mathrm{C}] \supset \diamond \sim \mathrm{C}$.

${ }^{10} \mathrm{~T} \supset \diamond \mathrm{T}$ and $\mathrm{C} \supset \diamond \mathrm{C}$.

${ }^{11}$ St. Thомаs, Summa Theologiae, 1:23:5.
} 
The down arrow to the right means that God actualizes the effect: glory (for the person acting).

The horizontal arrow marks the relation of the human free act, here taken as moral ("merit" or "demerit") to the effect. Thomas says that the act is a cause or reason (causa, ratio) for the effect. But this does not mean that the person brings about the effect all by himself, because God also actualizes his act (through grace), and this causality is symbolized by the down arrow to the left.

But this is the heart of the matter: two causes come together to bring about an effect. Scholastic theologians called this coming together concursus: two causes, one divine and one human, "run together" into the effect. Concursus was important for St. Thomas not only in the area of grace and predestination, but also on the natural level both in the operation of physical law and in human free choice. He insisted that we cannot eliminate either physical causality or free human decision in the name of God's sovereignty.

All things that act either naturally or voluntarily arrive of their own accord, as it were, at what they are divinely ordered to- and so God is said to "arrange all things properly". 12

If there were no physical law, things would be puppets and the natural sciences, says Thomas, would disappear since all science would be theology. If there were no free choice, we, too, would be puppets, no different from things, incapable of moral responsibility.

\section{Left-wingers and the right-wingers}

Here, by the way, the angels fear to tread, because for 750 years people have argued over what St. Thomas meant by concursus and from the $16^{\text {th }}$ century theologians, Protestants and Catholics alike, have wrestled with the puzzles of grace and free will. Around 1600 the dispute between Jesuits and Dominicans became so contentious that the pope (Clement VIII) told them to come to Rome and fight it out there. This gathering was called the Congregatio de auxiliis (the "commission on helps", that is, grace). They argued for almost ten years and got nowhere, so the next pope (Paul V) told them to cool it- and forbade Jesuits to call the Dominicans "Calvinists" and the Dominicans to call the Jesuits "Pelagians".

\footnotetext{
12 “Unde omnia quae agunt vel naturaliter vel voluntarie, quasi propria sponte perveniunt in id ad quod divinitus ordinantur-et ideo dicitur Deus 'omnia disponere suaviter'." St. Thomas, Summa Theologiae, 1:103:8. The last phrase is a quotation from the Book of Wisdom, 8:1 (in the sed contra St. Thomas also quotes Boethius referring to this

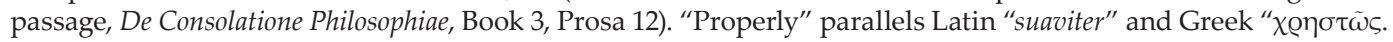


I am considering only natural human acts and God's natural causality, and this only from the logical point of view. We have two things in play here: (1) God's omnicausality or sovereignty and (2) man's freedom. You can deny or emphasize either at the expense of the other: (1) the leftists side with human freedom over God's causality and (2) the rightists side with God's causality over human freedom.

Of course to deny one side or the other would eliminate concursus completely, since there would not be two things "running together." It would eliminate the problem as well- but not solve it! The denials are the far left and the far right. The far-left denies that God causes everything; the far-right denies that man is free. Pelagianism is to the far left and Calvinism, at least if it means that man lacks free will because of God's sovereignty, would be to the far right.

\section{Scholastics on the left and on the right}

To tackle the problem we must, I think, speak of emphases within concursus. The Jesuits and Dominicans accepted both emphases, but the Jesuits were on the left, because they stressed human freedom, and the Dominicans on the right, because they stressed God's omnicausality. Luis Molina was the prominent Jesuit in the controversy and Domingo Bañez the prominent Dominican. The Protestant Arminian position would also be on the left in comparison to Calvinism.

Let us use the expression "Ep" to mean that God "effects p." The Scholastics used the concepts of causality (E), entailment $(\supset)$ and modality $(\diamond, \square)$ in their discussions. The Jesuit principle, where "EC" means that God "effects Caesar's choosing to cross the Rubicon", is

\section{CつEC}

"if Caesar chooses to cross the Rubicon, then God effects his choosing." So God effecting Caesar's deciding is a necessary condition for his deciding ("no effecting, no deciding").

But does not this leftist position imply that God only "seconds" Caesar's choice, once made? The Jesuits answer that time-wise Caesar does not decide before God effects his decision; rather the two events occur at the same time. For we tend to think that in causation the cause (E in EC) occurs before the effect ( $\mathrm{C}$ in EC), and in entailment that the antecedent ( $\mathrm{C}$ in $\mathrm{C} \supset \mathrm{EC}$ ) occurs before the consequent (EC in C $\supset \mathrm{EC}$ ). Yet the denial of this principle $-\mathrm{I}$ mean if we assert $\sim[\mathrm{C} \supset \mathrm{EC}]$, equivalent to $\mathrm{C} \wedge \sim \mathrm{EC}^{13}$ ("Caesar decides without God effecting his deciding")- smacks of Pelagianism.

${ }^{13} \sim[\mathrm{C} \supset \mathrm{EC}]=[\mathrm{C} \wedge \sim \mathrm{EC}]$. 
This principle (pつEp), by the way, is not general, since it does not apply to all state-of-affairs, but only contingent ones like T or C. If $\mathrm{p}$ is $2+2=4$, the entailment is false because God does not "effect" or "create" logically necessary facts (which have a quite different relation to God). ${ }^{14}$

Bañez stated two principles. His first, which lies on the right, is

\section{ECつC}

"necessarily: if God effects Caesar's decision, then Caesar decides to cross the Rubicon." Here Caesar's deciding (C) is a necessary condition for God effecting it (EC) ("no deciding, no effecting"), or the other way around: God's effecting (EC) is the sufficient condition of Caesar deciding.

But does this position imply that man is but a puppet? The Dominicans answered that God, as He effects Caesar's deciding, does not suppress his freedom. However, the denial of this principle -that is, the assertion [EC $\supset$ C]- seems absurd, for it is equivalent to EC^ C:15 "it is possible that God effects Caesar's deciding without Caesar deciding."

Bañez, however, softens EC $\sim \mathrm{C}$ by slipping in the possibility operator $\diamond$ before $\sim \mathrm{C}$; so that his second, modal, principle is:

\section{$\mathrm{EC} \wedge \diamond \sim \mathrm{C}$}

"God effects Caesar's deciding to cross the Rubicon but it is possible that Caesar does not so decide". ${ }^{16}$ If we combine these two principles -actually, the first principle $(\mathrm{EC} \supset \mathrm{C})$ and second conjunct $(\diamond \sim \mathrm{C})$ from the second-, we get what we might call the Bañezian principle:

$$
\text { ECつ }[\mathrm{C} \wedge \diamond \sim \mathrm{C}]
$$

"if God effects Caesar's choosing, then Caesar does choose but it is possible that he does not choose".

\footnotetext{
${ }^{14}$ Cf. Redmond, Deus et Logica/ Logica Theologiae Philosophicae Insita, Mexico: Porrúa, 2014, 1.3.

$15 \sim[\mathrm{EC} \supset \mathrm{C}] \equiv[\mathrm{EC} \wedge \sim \mathrm{C}]$.

${ }^{16}$ Bañez said that it would be wrong to take the expression "in the composite sense" (in sensu composito or de dicto); that is, to put the possibility operator $\diamond$ before the conjunction $\mathrm{EC} \sim \mathrm{C}(\diamond[\mathrm{EC} \sim \mathrm{C}])$, because, combined with the first principle ECEC, it would lead to the contradiction: $\mathrm{C} \wedge \mathrm{C}$. The operator then must be taken "in the divided sense" (in sensu diviso or de re) to affect only the second conjunct $(\diamond \sim \mathrm{C})$.
} 


\section{Left plus right and the creation principle}

It is important to see that the Jesuit and Dominican positions (thus interpreted logically) are not logically contradictory. In fact we may combine the two principles C $\supset$ EC and EC $\supset[\mathrm{C} \wedge \diamond \sim \mathrm{C}]$, and if we do, ${ }^{17}$ we obtain two entailments: EC $\supset[\mathrm{C} \wedge \diamond \sim \mathrm{C}]$ and $[\mathrm{C} \wedge \diamond \sim \mathrm{C}] \supset \mathrm{EC}$ and therefore the equivalence:

$$
\mathrm{EC} \equiv[\mathrm{C} \wedge \diamond \sim \mathrm{C}]
$$

"God effects that Caesar decides to cross the Rubicon if and only if Caesar does so decide and it is possible that he does not so decide."

Interestingly, this Scholastic principle is nothing but the creation principle, since it is true generally:

$$
\mathrm{Ep} \equiv[\mathrm{p} \wedge \diamond \sim \mathrm{p}]
$$

"God effects the state-of-affairs $p$ just in case $\mathrm{p}$ is actual but it is possible that $\mathrm{p}$ is not actual", or in other words "if God effects a state-of-affairs, it is contingent, and if a state-of-affairs is contingent, God effects it." Its denial, $\sim[\mathrm{Ep} \equiv[\mathrm{p} \wedge \diamond \sim p]]$, would be "atheistic", since it is equivalent to: (1) either God effects $p(E p)$ yet $p$ is either not actual ( $\sim$; ; but Ep $\diamond p$ ) or necessary ( $\square$ p; false), (2) or else God does not effect p ( $\sim$ Ep) yet $\mathrm{p}$ is actual (p; but $\sim \mathrm{Ep} \supset \sim \mathrm{p})$ and $\mathrm{p}$ is contingent $(\mathrm{p} \wedge \diamond \sim \mathrm{p})$ without God effecting $\mathrm{p}(\sim \mathrm{Ep})$.

Therefore the Scholastic principle $\mathrm{Ep} \equiv[\mathrm{p} \wedge \diamond \sim \mathrm{p}]$ is true of any created state-of-affairs, whether free like $C$,

$$
\mathrm{EC} \equiv[\mathrm{C} \wedge \diamond \sim \mathrm{C}],
$$

or determined like $\mathrm{T}$.

$\mathrm{ET} \equiv[\mathrm{T} \wedge \diamond \sim \mathrm{T}]$.

So we have Moore's problem again, since the Scholastic principle is not specific to human freedom!

\section{The Scholastic principle}

Now, if we wish to limit God's effecting to human decision, we must add that Caesar's choosing is not determined by physical law: $\sim[\mathrm{L} \supset \mathrm{C}]$ or equivalently $\diamond[\mathrm{L} \wedge \sim \mathrm{C}]$. The result is $\mathrm{EC} \equiv[\mathrm{C} \wedge \diamond \sim \mathrm{C} \wedge \diamond[\mathrm{L} \wedge \sim \mathrm{C}]]$, but because the possibility of $\sim \mathrm{C}$

\footnotetext{
${ }^{17}$ Together they also entail $\mathrm{C} \supset \diamond \sim \mathrm{C}$.
} 
$(\diamond \sim \mathrm{C})$ already follows from the fact that it is not physically determined $(\diamond[\mathrm{L} \wedge \sim \mathrm{C}]),{ }^{18}$ we can simplify the formula in this way:

$$
\mathrm{EC} \equiv[\mathrm{C} \wedge \diamond[\mathrm{L} \wedge \sim \mathrm{C}]]
$$

"God effected Caesar's deciding to cross the Rubicon if and only if Caesar did indeed so decide, but it was possible that he does not so decide while physical law is in force." $\mathrm{ET} \equiv[\mathrm{T} \wedge \diamond[\mathrm{L} \wedge \sim \mathrm{T}]]$ of course is false.

This logic, I believe, pinpoints the heart of the problem, which is concursus: the $\mathrm{EC}$ in $\mathrm{EC} \equiv[\mathrm{C} \wedge \diamond[\mathrm{L} \wedge \sim \mathrm{C}]]$, where what God does and what creatures do "run togeth$\mathrm{er}^{\prime \prime}$. But the logic hardly solves the problem, because it needs metaphysical analysis: how, as St. Thomas said, does God "arrange all things properly"- where some things act naturally but others voluntarily to get to what God "orders" them to?

Far-left positions lead to greater paradox. We must rather blend the left and the right and say with Sherlock Holmes:

When you have eliminated the impossible, whatever remains, however improbable, must be the truth. ${ }^{19}$ 